\title{
Patients who experience systemic lupus erythematosus and leg ulcer: phenomenological approach
}

\author{
Experiência vivenciada por pacientes com lúpus eritematoso sistêmico e úlcera da perna: abordagem fenomenológica \\ Experiencia vivida por pacientes con Lupus Eritematoso Sistémico y Úlcera de la Pierna: abordaje fenomenológico
}

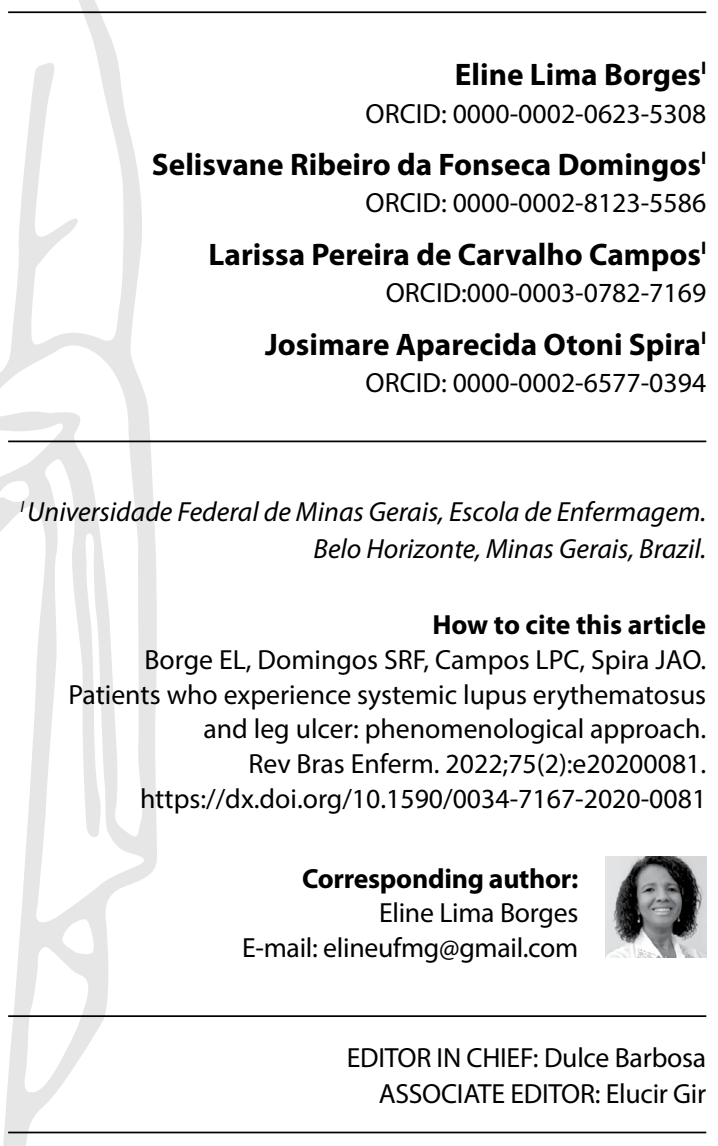

Submission: $04-29-2020$
Approval: 07-19-2021

\begin{abstract}
Objective: To understand the experience of a woman with systemic lupus erythematosus and leg ulcers with cutaneous calcinosis. Methods: An experience report based on the social phenomenology of Alfred Schutz, conducted with a young woman undergoing treatment in an outpatient service. Results: The disease manifested itself in adolescence and brought emotional instability associated with body image concern and social isolation. The discontinuation of the studies triggered financial limitations with implications for treatment. The presence of ulcers aggravated by skin calcification makes the process of getting sick tiring and painful. Interpersonal relationships are resources for coping with situations experienced. Final considerations: Patients with lupus may have social, affective, and family life, even in the face of the limitations imposed by the disease. However, the emergence of leg ulcer with calcinosis changes this situation.

Descriptors: Patients; Leg Ulcer; Lupus Erythematosus Systemic; Qualitative Research; Life
\end{abstract} Change Events.

\section{RESUMO}

Objetivo: Compreender a experiência de uma mulher com lúpus eritematoso sistêmico e úlceras da perna com calcinose cutânea. Métodos: Relato de experiência amparado na fenomenologia social de Alfred Schutz, realizado com uma jovem em tratamento em um serviço ambulatorial. Resultados: A doença manifestou-se na adolescência e trouxe instabilidade emocional associada à preocupação com a imagem corporal e isolamento social. A interrupção dos estudos desencadeou limitações financeiras com implicações para o tratamento. A presença de úlceras agravada pela calcificação cutânea torna o processo de adoecimento cansativo e doloroso. As relações interpessoais são recursos para o enfrentamento das situações vividas. Considerações finais: É possível que pacientes com lúpus possam ter vida social, afetiva e familiar, mesmo diante das limitações impostas pela doença, entretanto o surgimento da úlcera da perna com calcinose altera essa situação.

Descritores: Pacientes; Úlcera da Perna; Lúpus Eritematoso Sistêmico; Pesquisa Qualitativa; Acontecimentos que Mudam a Vida.

\section{RESUMEN}

Objetivo: Comprender la experiencia de una mujer con lupus eritematoso sistémico y úlceras de la pierna con calcinosis cutis. Métodos: Relato de experiencia amparado en la fenomenología social de Alfred Schutz, realizado con una joven en tratamiento en un servicio ambulatorio. Resultados: La enfermedad se ha manifestado en la adolescencia y trajo inestabilidad emocional relacionada a la preocupación con la imagen corporal y aislamiento social. La interrupción de los estudios desencadenó limitaciones financieras con implicaciones para el tratamiento. La presencia de úlceras agravada por la calcificación cutánea vuelve el proceso de enfermedad cansado y doloroso. Las relaciones interpersonales son recursos para el enfrentamiento de las situaciones vividas. Consideraciones finales: Es posible que pacientes con lupus puedan tener vida social, afectiva y familiar, mismo delante de las limitaciones impuestas por la enfermedad, entretanto el surgimiento de la úlcera de la pierna con calcinosis altera esa situación.

Descriptores: Pacientes; Úlcera de La Pierna; Lupus Eritematoso Sistémico; Investigación Cualitativa; Acontecimientos que Cambian la Vida. 


\section{INTRODUCTION}

Systemic lupus erythematosus (SLE) is a chronic, multisystem, and autoimmune inflammatory disease characterized by the presence of several autoantibodies ${ }^{(1)}$. In Europe and Central America countries, the prevalence of the disease is well established, with rates ranging from 20 to 200 per 100 thousand people ${ }^{(2)}$. Epidemiological data in Latin American countries are scarce but estimates show that the disease in Brazil has a prevalence ranging from 14.6 to 122 cases per 100 thousand inhabitants, with a higher incidence in women than in men, in a ratio of 9:1, and can occur mainly in young women, but in all races ${ }^{(3)}$.

SLE can simultaneously or successively compromise the integrity of bones, joints, muscles, kidneys, heart, lung, the central nervous, blood, eye, auditory, and integumentary systems ${ }^{(1)}$. The manifestations and severity of the disease vary according to the affected system, racial/ethnic origin, and socioeconomic condition of the patients ${ }^{(1)}$. Regarding skin manifestations, leg ulcers stand out, defined as a discontinuity of the skin barrier below the knee level that persists for more than six weeks and does not show a tendency to heal after three months of appropriate treatment ${ }^{(4)}$.

Vasculitis, antiphospholipid antibodies, gangrenous pyoderma, or cutaneous calcinosis causes ulcers arising from lupus $s^{(5)}$. Calcinosis is a rare disease, of little known pathophysiology, characterized by the deposition of calcium salts in injured or devitalized tissues in the skin, subcutaneous tissue, muscles, and tendons without visceral involvement ${ }^{(6)}$. Such a process generates the maintenance of the lesion, increasing the impact and causing restrictions in the patient's life ${ }^{(7)}$.

Lupus has repercussions on people's lives, especially when it forces them to move away from professional and occupational activities, directly affecting the economic condition, in a context of limitations, especially when one is young. When associated with an ulcer, the impact on quality of life is even higher due to changes in human physiological, social, security, esteem, and personal fulfillment needs $s^{(4)}$. Such changes generate stress and suffering for these people(8).

Chronic disease in women influences aspects such as femininity, affectivity, self-image, sensitivity. When affected by lupus, the impact is more intense due to the physical changes that this disease causes, requiring constant care and continuous adaptation, which affects the quality of life. Women start to deal with a new dimension in their lives ${ }^{(9)}$.

To that end, there is a need for a better understanding of the emotional aspects involved in SLE illness, especially among women, so that professionals can serve this clientele holistically, minimizing suffering and ensuring adherence to treatment ${ }^{(10-11)}$.

SLE research generally addresses clinical aspects of the disease, complications, and associations with other morbidities ${ }^{(12-14)}$. Concerning subjective issues, some studies have been identified on the experience of people with the disease, considering the psychological and psychiatric problems, in addition to the impacts that it can bring to the life of the sick person and social and family relationships $s^{(9,15)}$.

For more than a year, the outpatient follow-up of a young woman with SLE for the treatment of leg ulcers aggravated by cutaneous calcinosis, living in a complex social, economic and psychological context, aroused interest in the researchers and led them to the following concerns: how does this woman feel having SLE, being young, and with leg ulcers? What factors are involved in the process of treating these skin lesions? What are her care needs? What does this woman expect from health professionals? What are her life projects?

\section{OBJECTIVE}

To understand the experience of a young woman with systemic lupus erythematosus and leg ulcers with cutaneous calcinosis.

\section{METHODS}

\section{Ethical aspects}

The research obtained data with the consent of the patient after signing the Informed Consent Form according to resolution 466/2012 of the National Health Council. The study project was approved by the Research Ethics Committee of the Federal University of Minas Gerais (UFMG).

\section{Type of study}

This is an experience report according to the social phenomenology of Alfred Schutz.

\section{Theoretical-methodological framework}

The social phenomenology of Alfred Schutz proposes the understanding of phenomena through the real experience in everyday life, allowing access to human consciousness in its essence. For Schutz, the social world is regarded as the time and space where human beings share meaningful conscious processes of themselves and others. In it, social relations take place through intersubjectivity. To live in the world of life, man is guided by the way he defines the action scenario, interpreting its possibilities and challenges and using his body of knowledge, which is constituted in the background of previous experiences and information transmitted culturally by parents, teachers, and people who live in the social world. Thus, every human action is endowed with intentionality and is related to a project in which man finds meaning, that is, actions are motivated behaviors. Thus, the author states that "reasons- why" hold on to the sedimented past in the consciousness of the human being and are linked to the background of knowledge acquired and experienced. Concerning the "reasons-for," it refers to the intentionality that triggers the action and is grounded in the knowledge pool ${ }^{(16)}$.

\section{Subject of the study}

A woman diagnosed with SLE and ulcers on the lower limbs with cutaneous calcification.

\section{Study setting}

The setting was the Belo Horizonte outpatient service that receives patients with chronic injuries of various etiologies. 
In this facility, patients are followed once or twice a week by nurses specialized in dermatology and/or stomatotherapy, and these nursing visits follow the premises of the nursing process, according to resolution COFEN No. 358/2009. The nurses follow a clinical protocol related to the treatment of chronic wound patients on an outpatient basis, and this document guides the care activities developed by health professionals and how data should be collected and recorded in the medical record.

\section{Collection and organization of data}

The data collection was carried out in January 2019, through an open interview of phenomenological modality, in a private office, with the presence of the patient and researcher, lasting one hour. The researcher used the following questions: "For you, how is living with lupus and leg ulcers? What do you expect from the health professionals who perform your care? What are your projects?"It is important to emphasize that the phenomenological interview requires a face-to-face relationship, which makes it possible to remain open and accessible to the intentional acts of the other, constituting a permissible "relationship us," so that the researcher learns the flow of the consciousness of the subject ${ }^{(16)}$.

The interview was recorded and transcribed immediately after its completion, considering the subjective aspects involved, such as the expression of the emotions. The researchers organized the data into specific categories that emerged from the participant's testimony. The following steps were intended for the construction of the categories, as recommended by scholars of social phenomenology of Alfred Schutz ${ }^{(17)}$ : a careful and sensible reading of the transcribed material to identify and grasp the overall meaning of the experience; re-reading of the testimony with identification of the units of meaning; a grouping of the units of meaning based on the "reasons-why" and"reasons-for;" construction of concrete categories.

\section{Data analysis}

The focus of this study is the impact of ulcers on the life of a woman with SLE. Thus, two categories emerged from the testimony of the participant. The first, called "the experience of living with lupus", refers to the "reasons-why" and reveals the context of meanings experienced by the woman. And the second, called "an uncertain future," refers to the "reasons-for" and expresses the woman's expectations. The data were analyzed from the perspective of Alfred Schutz's social phenomenology framework and discussed with the relevant literature.

\section{RESULTS}

\section{The experience of living with lupus}

A 32-year-old woman, literate, with eight years of study, single, brown, diagnosis of SLE with cutaneous involvement, alopecia, arthralgia, bilateral femoral head osteonecrosis with prosthesis on the left, obese, major depressive disorder, and ulcers in the lower limbs associated with cutaneous calcification. The medications used were prednisone methadone, gabapentin and fluoxetine, calcium carbonate, vitamin D3, hydrochlorothiazide, dipyrone, and paracetamol.
Upon admission to the service, the patient had two recurrent ulcers, one in the left leg and the other in the right leg, both in the anterior region, which arose as a result of trauma (Figure 1).
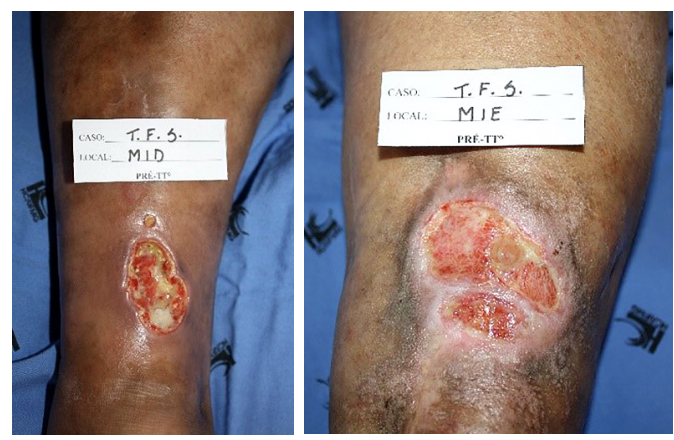

Figure 1 - Ulcers of the anterior region of the right legs (with an area of $13.5 \mathrm{~cm}^{2}$ ) and left (with an area of $28.8 \mathrm{~cm}^{2}$ ) at the time of admission to the outpatient clinic

After three months of treatment, a new lesion appeared in the posterior region of the right leg, resulting from the skin biopsy performed to investigate vasculitis (Figure 2).

The lower limbs had edema, critically colonized ulcers, with large amounts of serous exudate, evident odor when exposing the bandage, thick and well adhered to the lesion bed, and reports of severe pain. The previous topical treatment was at home and consisted of daily application of amorphous hydrogel with gauze.

After admission, the patient attended nursing appointments twice a week for treatment of ulcers. The topical treatment consisted of interactive covers, and its choice was carried out according to the need for management of exudate, odor, devitalized tissue, signs of critical colonization or infection, perilesional skin, and pain. To manage edema, nurses instituted inelastic compressive therapy (Unna boot).

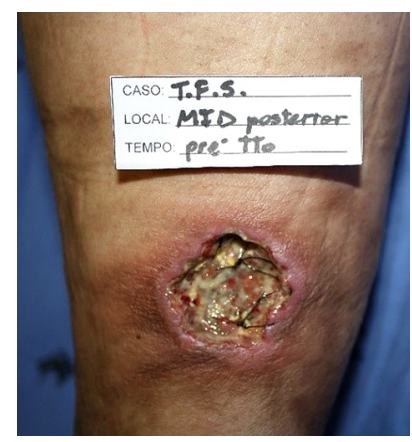

Figure 2 - Ulcer of the posterior region of the right leg at the time of admission to the outpatient clinic, with an area of $11.55 \mathrm{~cm}^{2}$

In the period before the study, the patient had suffered a hospitalization due to the complication of lupus. The ulcers of the anterior and posterior regions of the right leg presented increased area, presence of yellowish necrotic tissue, production of a large amount of serosanguinolent exudate with an unpleasant odor and evident at a distance of half a meter from the patient, inflammatory signs, presence of microcalcifications and reports of severe pain. The left leg ulcer presented a better appearance, 
reduction of the injured area, presence of yellowish necrotic tissue, production of a large amount of serous exudate, no odor, and no reports of pain (Figure 3 ).

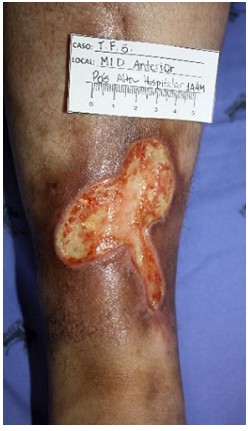

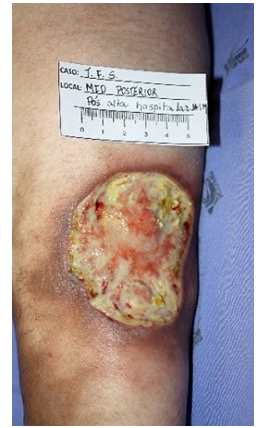

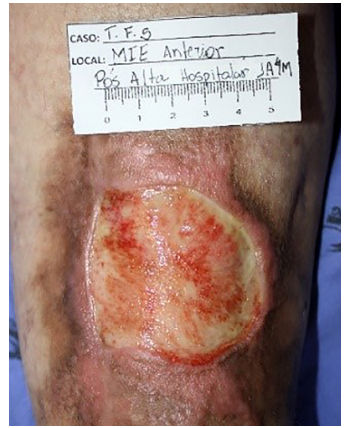

C
Figure 3 - Leg Ulcers in the anterior regions of the right leg with an area of $40.3 \mathrm{~cm}^{2}(\mathrm{~A})$, posterior of the right leg with an area of $58.5 \mathrm{~cm}^{2}(\mathrm{~B})$, and anterior of the left leg with an area of $35.1 \mathrm{~cm}^{2}(\mathrm{C})$

Due to the complexity of the care required, in addition to the treatment of ulcers in the outpatient service, the patient is accompanied by professionals of dermatology, rheumatology, pain, and psychiatry clinics. In addition, she receives social assistance.

Reflecting on the experience of having lupus, the participant recalls her past and describes how challenging her trajectory was from the onset of symptoms, which arose in adolescence, to the confirmation of the disease.

[...] it started when I was 14 years old. [...] the joints began to swell and hurt too much. [...] that stain started to form, the famous butterfly wing. [...] then, I did several exams [...] until we discovered it was Lupus. [...] Then, after that, I began the journey that is to this day.

This trajectory was marked by emotional instability linked to concern about body image and limitations in the financial conditions necessary for treatment. Thus, it generated serious consequences in the life of this woman, such as interruption of studies and social isolation.

[...] at first, it was complicated because the whole skin got stained. With that, my emotional health was very shaken. [...] at school, I had a lot of jokes and looks that bothered me. So, I isolated myself. [...] I gave a break. [...] I stopped going to school for around six months. I just stayed indoors. [...] At that time, I couldn't afford medications. Then, with this, the disease started to progress.

The suffering experienced at the beginning of the disease discovery process was potentiated by people's ignorance and prejudice about lupus.

Lupus is a disease that has a lot of prejudice because people do not know what it is. So, when I say it's an autoimmune disease, people already think it's a contagious disease.

Lupus is a chronic and incurable disease, which brings consequences in daily life since the unpredictability of the progression and remission of symptoms, accompanied by the emergence of new conditions, requires a permanent commitment of the person. Thus, living with lupus is considered a tiring process.

Tiring because it is a continuous treatment, unending treatment. It is incurable. Lupus is a very ungrateful disease. [...] You go through a long treatment and always get bad results. Like, you're treating one thing, when you think you're getting better from that problem, lupus throws you another problem to keep treating.

Over time, complications of the disease arise, making this journey more difficult, leading to discouragement and distrust regarding a possible improvement.

I just had the skin lesions. Now, over the years, it began to attack the heart, lung [...]. So, we end up discouraging with the time.

The woman highlighted that leg ulcers with cutaneous calcification made the disease process more tiring and painful, particularly because of recurrent infections.

It's a tiring process. Tiring and time-consuming. [...] I've been bandaging my wounds for a year and six months. [...] The wound treatment makes me tired too. It's tiring and painful. [...] Even more because of these calcifications that come out. It's even more painful. They help to infect more and open more.

Ulcers on the legs aggravate emotional instability, already established by the condition of the disease, since they impose limitations on personal and social life, resulting in isolation.

[...] emotional health is compromised. [...] you can't do the things you like. How do you take a bath right with both legs injured? How do you go to a waterfall or a pool with your legs like that? How do you go to a place you like to have fun? So, it ends up banning you and isolating you from a lot of things.

The participant emphasizes the difficulties to achieve and maintain a paid work due to the physical manifestations of the disease that alter body image, cause severe pain and trigger emotional alteration.

Service is complicated. It is very difficult to get it because lupus has a phase that your skin is good, has a phase that your skin is bad, that you are well and that you are bad. [...] companies take appearance very seriously [...]. It was very difficult to get a job. Lately, I have stayed away. It is very difficult because somedays you are well, others, you are in pain, with injured skin [...] they are unbearable pains.

Having Lupus and living with leg ulcers with cutaneous calcinosis is a process permeated by limitations and intense suffering, given the expected complications with the evolution of the disease and the difficulties imposed by the treatment. In this context, interpersonal relationships are a relevant resource for coping with the situations presented, highlighting the importance of the family and health professionals.

The statements describe that the family's participation is superficial support and highlight that family members treat her like a normal person because they live with the disease and its manifestations, unlike external people. However, they point out 
that the family is predominantly concerned with the control of the disease, assisting her to follow what is allowed or prohibited.

They know I have lupus [...]. They treat me like a normal person. [...] there's always someone to warn you, call your attention. But all worry [...].

It is important to note that during outpatient visits for care and treatment of injuries, the patient is always alone and almost does not talk about her family, even when questioned.

Regarding the care received from health professionals, the statements show that there is a concern with her individuality shown through offering support and attention, and it makes her feel well cared for.

They take care of me very carefully. Lots of attention and affection, even when I'm stressed.

\section{An uncertain future}

When expressing what she expects for her life through the "reasons-for," the participant of this study reports that she does not have many expectations. Knowing the disease and its evolution, she understands some issues, such as the impossibility of pregnancy due to the risk of complications involved. However, it does not prevent a new family from being built.

I can imagine my life alone. Lupus and children, no chance. Raise a family, who knows? [...] because nothing is impossible for God.

The suffering experienced since the beginning of the disease, the definition of diagnosis and treatment, and the unpredictability of the progression of symptoms and complications make the path rockier, slowing down and even canceling their life projects.

Honestly, I don't have any plans. [...] I have no illusions about anything. [...] I don't have it because the disease let me down. Let down by the fact that It's always there.

Without prospects for the future, suffering increases. It's like walking in the dark. Patients do not know what they will find ahead. They experience a world permeated by uncertainties.

\section{DISCUSSION}

SLE is a chronic disease that generates multiple symptoms, whose diagnosis is difficult to define to establish the appropriate therapy for its control ${ }^{(9)}$. In the present study, the discovery of lupus triggered a moment of emotional instability due to the difficulty in defining the diagnosis and accepting a new life condition imposed by limitations. Dealing with waiting for the definition of the diagnosis is a generating moment of anxiety and uncertainties ${ }^{(18-19)}$.

After obtaining the diagnosis, patients start to live a life of limitations and intense suffering due to the physical manifestations and psychic and social repercussions of the disease. Therefore, qualitative studies reveal that changes in body image, financial difficulties to conduct the treatment, school and work abandonment, and lack of understanding of the disease by third parties aggravate this suffering ${ }^{(20-21)}$.
Living with lupus means being doomed to a daily struggle imposed by many difficulties since treatment adherence is not enough for disease stagnation. The recurrence of symptoms and the emergence of complications make this process tiring, leading to the experience of fatigue faced negatively by hindering adjustments in routine activities ${ }^{(18-19)}$. However, knowing the psychological impacts that the disease can bring is incipient ${ }^{(22)}$.

Factors such as the fluctuating course of the disease, the physical and physiological functioning of the body, the long-term treatment with the side effects and resulting damage, and the impairment in activities can trigger anxiety and depression ${ }^{(23)}$.

The study patient scored physical changes caused by lupus, such as skin spots, body pains, injuries, leg ulcers, and difficulty in walking as factors that hinder her insertion and maintenance in the labor market and, therefore, increase economic and social problems. In cases of patients with low income, the study showed that there is a difficulty in following drug treatment, generating worse quality of life, increased activity of the disease, and, consequently, greater harm to the body ${ }^{(23)}$.

Another point to highlight is the frequent presence of pain caused by leg ulcers, making treatment challenging. Chronic pain can affect several aspects of an individual's life, causing impairments in quality of life and associated with mood disorders ${ }^{(24)}$.

In lupus, leg ulcers usually occur due to vasculitis and rarely due to cutaneous calcinosis ${ }^{(5)}$. The latter was present in the study patient. Calcinosis is a complication characterized by calcium deposition in soft tissues, usually associated with trauma, infection, or inflammation. This process is poorly known in the literature, and there is still no stipulated protocol for its treatment ${ }^{(25)}$.

During the dressing change on the patient, calcium crystals are removed as they are expelled by the body and exposed to the lesion area. This process is necessary, although it makes the ulcer cleaning procedure more uncomfortable.

A prospective cohort of patients with SLE evaluated the variation of pain concerning the disease for seven years. It found that the decrease in pain was associated with decreased fatigue, anxiety, and depression, and the improvement in the quality of life was related to health. Patients with high levels of pain in the follow-up maintained a high degree of fatigue and low quality of life regarding health ${ }^{(26)}$.

Dermatological conditions can produce adverse effects on the patient's life since we live in a society that sets aesthetic standards and everyone is encouraged to incorporate them from a young age. Thus, people who do not fit this pattern face curious and prejudiced looks due to social stigmas linked to contagion and personal unrest. It can interfere with their self-esteem (an important indicator of mental health) and self-image, providing the manifestation of problems such as anxiety, depression, and social isolation ${ }^{(27)}$.

Psychological stress is a relevant matter in the development and maintenance of the disease and its aggravations since it is a chronic, incurable and unpredictable disease. Thus, disorders in SLE patients encompass a variety of psychiatric findings, which can lead to chronic disabilities, providing profound psychological suffering ${ }^{(28)}$.

According to a study carried out in southern Brazil, skin lesions bring great disorders to the people who have them, as well as to their family network. It occurs mainly due to psychological, social, and economic repercussions, and authorities consider it as a public health problem. The prolonged duration of treatment causes the 
social network to become the principal support of the patient in this period. Thus, the nursing team must identify these people to share patient care and adherence of patients and families through educational, preventive, and curative treatment activities ${ }^{(29)}$. The emotional support offered by social relationships can positively influence the self-esteem and autonomy of patients, providing better adherence to treatment.

The present study shows frustration on the part of the patient since, even in the face of her dedication and effort to perform the treatment of lupus and leg ulcers, the disease maintains remissions and progressions that make the therapy exhausting. Treatment strategies for SLE seek, in most cases, to reduce the damage caused by the disease and reduce morbidity, thus increasing the longevity and quality of life of people affected by this disease. However, they do not promote cure ${ }^{(30)}$.

Study results conducted with South African women showed that lupus is related to complex, chronic, and challenging life experiences. All participants experienced emotional problems, often linked to suicidal thoughts. Many have experienced difficulties with fertility and pregnancy, resulting in confusion and depression. Physical disfigurements resulting from alopecia and lupus-associated skin rashes and corticosteroid-induced weight fluctuations were a significant concern. These changes often affect self-image and libido, leading to strained personal relationships. The study found that the poor understanding of lupus by the participant's family and community, together with the unpredictable course of the disease, were factors that exacerbated frustration with social exclusion ${ }^{(31)}$.

A study conducted with South Asian women with SLE revealed that some of these women consider lupus an arduous disease to deal with, although they can camouflage and soften them through social and professional relationships, and that depression makes the treatment process longer than it should be $\mathrm{be}^{(32)}$.

There is disagreement about what factors trigger depressive illness in people with SLE. External factors, such as the disruption of social networks, appear as a severe problem for these patients since social support is an essential ally in the therapy of people with so many susceptibilities ${ }^{(23)}$. In the case of the study patient, reports showed that she received support from the family, especially from her mother and siblings, to help her needs.

The person with lupus demands individual and planned multidisciplinary care and psychological support from the family and health team both at the time of diagnosis and in the course of the disease since it is a disease closely related to death. Knowing the self-perception of the patient with the disease leads to the adoption of more effective and efficient interventional measures for comprehensive, biopsychosocial care, increasing adherence to treatment, and decreasing associated morbidity ${ }^{(22)}$.

Even in the face of the difficulties of treatment and limitations imposed by the disease, the patient's perspectives regarding her future involve raising a family. The social bonds in the patient's life, as well as the type and quality of the relationships that configure them, are essential to face the situations experienced since family isolation of the patient with chronic disease is frequent and can leave the patient more vulnerable to emotional disorders ${ }^{(33)}$. According to the patient's narrative, the professional team that assists her in the outpatient clinic is also considered essential support for coping with the disease. This support is part of the holistic view of professionals with the patient and it allows them to understand not only the illness and pain as a physical but also an emotional limitation. The support of professionals is essential because depression is a frequent emotional condition in people with chronic pain ${ }^{(34)}$.

Professional care implies a kind of social relations between individuals. It adds to factual care the technoscientific dimension that differentiates it from that practiced by common sense, in addition to being based on intersubjectivity, the collection of knowledge and the biographical situation of the professional caregiver ${ }^{(35)}$.

Concerning marital relationships, the patient manifests a certain disappointment. A literature review on the life perspective of people with SLE found that they can feel useless and hopeless. Body changes make women feel less attractive and confident, plus social stigma intensifies their loss of self-esteem ${ }^{(36)}$.

In addition to the fear of getting married, the participant demonstrates that she repels the possibility of having children through her narratives, given her health condition. Besides the genetic predisposition offered by the disease, few studies discuss the effects of drugs used for treatment in pregnant women and whether the damage is caused by the medication or the disease. Thus, women should postpone pregnancy until a stage of stability of the disease, because otherwise, it may provide cases of abortion and prematurity of babies ${ }^{(37)}$.

Regarding the perspectives on the quality of life of people with lupus, the study highlights the anxiety of the disease's development, as well as the aggravation or spread to new organs. The concern can also be associated with unpleasant experiences throughout the disease condition. Recurrence of pain, weakness, and permanent tiredness are also responsible for this hopelessness. Many patients fear the progression of the disease and even death ${ }^{(38)}$.

The presence of leg injury characterized as a rare complication in lupus makes the disease process more tiring, considering the expected complications with the evolution of the disease and the difficulties imposed by the treatment when it includes the ulcer. In this context, the study highlights the need for a support network to cope with the disease and maintain treatment because unpredictability about what might happen confirms an uncertain future and nullifies projects. However, it is necessary to consider the social being, inserted in the world of life, that is, in a world of social relations in which there is the desire to constitute a family, regardless of the possibility of having children or not.

It is feasible that people with lupus can have a regular life, even in the face of the limitations imposed by the disease, living fully their social, affective, and family life like anyone who has a chronic disease.

\section{Study limitations}

Since this study involves a single case, the results cannot be generalized. However, the rarity of cutaneous calcinosis in people with lupus justifies its importance.

\section{Contributions to the field of Nursing, Health, or public policy}

This study enables nursing and health professionals, in general, to plan care for these people and improve the quality of care 
provided, as well as promote the reception of biopsychosocial demands that emerge from their life contexts, enabling the adjustment of care technologies so that professionals can provide health care with greater resolution.

\section{FINAL CONSIDERATIONS}

Having Lupus and living with the unpredictability of progression and remission of symptoms is one of the main difficulties in dealing with the disease, which leads to emotional instability and, consequently, adjustments in everyday life. The context of meanings experienced by the participant of this study signals intense suffering since the discovery of the disease, with significant impacts on personal and social life, which make the future uncertain. The rationale of the findings from the perspective of social phenomenology allowed reflections that make it possible to value the intersubjective relationship between health professional and patient, which may favor greater adherence to care and better quality of life.

\section{REFERENCES}

1. Pons-Estel BA, Bonfa E, Soriano ER, Cardiel MH, Izcovich A, Popoff F, et al. First Latin American clinical practice guidelines for the treatment of systemic lupus erythematosus: latin american group for the study of lupus (GLADEL, Grupo Latino Americano de Estudio del Lupus) - Pan-American League of Associations of Rheumatology (PANLAR). Ann Rheum Dis. 2018;77(11):1549-57. http://doi.org/10.1136/annrheumdis-2018-213512

2. Mocarzel LOC, Lanzieri PG, Montes RA, Gismondi RAOC, Mesquita CT. Systemic lupus erythematosus: review of cardiovascular aspects. Int J Cardiovasc Sci. 2015;28(3):25-61. https://doi.org/10.5935/2359-4802.20150037

3. Bezerra ELM, Vilar MJP, Barbosa OFC, Santos SQ, Castro MA, Trindade MC et al. Lúpus eritematoso sistêmico (LES): perfil clínico-laboratorial dos pacientes do hospital universitário Onofre Lopes (UFRN-Natal/Brasil) e índice de dano nos pacientes com diagnóstico recente. Rev Bras Reumatol. 2005;45(6):339-42. http://doi.org/10.1590/S0482-50042005000600002

4. Agale SV. Chronic leg ulcers: epidemiology, aetiopathogenesis, and management. Ulcers. 2013;2013:9 pages. https://doi.org/10.1155/2013/413604

5. Lederhandler M, Whitney V, Zoghbi Z, Grossman ME. Leg ulcers in systemic lupus erythematosus associated with underlying dystrophic calcinosis and bone infarcts in the absence of antiphospholipid antibodies. JAAD Case Rep. 2016;2(2):164-7. https://doi.org/10.1016/j.jdcr.2016.02.009

6. Shinjo SK, Souza FHC. Update on the treatment of calcinosis in dermatomyositis. Rev Bras Reumatol. 2013;53(2):211-4. http://doi. org/10.1590/S0482-50042013000200009

7. Carocha APG, Torturella DM, Barreto GR, Estrella RR, Rochael MC. Calcinosis cutis universalis associated with systemic lupus erythematosus: an exuberant case. An Bras Dermatol. 2010;85(6):883-7. http:// doi.org/10.1590/\$0365-05962010000600016

8. Silva EB, Lima RBO, Silva JS, Cabral CVS. O lúpus eritematoso sistêmico e a autoimagem da mulher portadora. Rev Enferm UFPI. 2016;5(1):6772. https://doi.org/10.26694/reufpi.v5i1.4719

9. Alcantara GC, Aguiar CCM, Monteiro KCC. A vivência de mulheres com lúpus eritematoso sistêmico. Rev Psicol. 2011 [cited 2019 Jul 5];2(1):78-85. Available from: http://www.periodicos.ufc.br/psicologiaufc/article/view/76

10. Resende OLC, Barbosa MTS, Simões BFT, Velasque LS. The representation of getting ill in adolescents with systemic lupus erythematosus. Rev Bras Reumatol. 2016;56(5):398-405. http://doi.org/10.1016/j.rbre.2016.03.016.

11. Nowicka-Sauer K, Hajduk A, Kujawska-Danecka H, Banaszkiewicz D, Czuszyńska Z, Siebert J. Illness perception is significantly determined by depression and anxiety in systemic lupus erythematosus. Lupus. 2018;27(3):454-60. https://doi.org/10.1177/0961203317751858

12. Salman-Monte TC, Carrión-Barberà I, Pérez García C, Gimeno Beltrán J, Monfort J. Inflammatory myopathy and autoimmune hepatitis in a patient with a flare of systemic lupus erythematosus: an exceptional association. Eur J Rheumatol. 2018;5(3):197-200. https://doi.org/10.5152/ eurjrheum.2018.17135

13. Drenkard C, Bao G, Lewis TT, Pobiner B, Priest J, Lim SS. Physician-patient interactions in African American patients with systemic lupus erythematosus: Demographic characteristics and relationship with disease activity and depression. Semin Arthritis Rheum. 2019;48(4):66977. https://doi.org/10.1016/j.semarthrit.2018.05.012

14. Chiang Y-C, Huang J-L, Wang C-H, Lee H-C, Lee M-Y, Hsiao Y-C. Symptom clustering in patients with childhood-onset systemic lupus erythematosus. J Adv Nurs.2019; 75(1):54-62. https://doi.org/10.1111/jan.13825

15. Cordeiro SM, Andrade MBT. Desvelando a percepção do familiar da pessoa com lúpus eritematoso sistêmico. Rev Enferm UFPE. 2013;7(2):422-29. https://doi.org/10.5205/1981-8963-v7i2a10251p422-429-2013

16. Schutz A. El problema de la realidade social. Buenos Aires: Amorrortu; 2008.

17. Herreira Trigueiro T, Silva MH, Merighi MAB, Oliveira DM, Jesus MCP. Psychological suffering in the daily lives of women who have experienced sexual violence: a phenomenological study. Esc Anna Nery. 2017;21(3):e20160282. http://doi.org/10.1590/2177-9465-ean-2016-0282

18. Larsen JL, Hall EOC, Jacobsen S, Birkelund R. The existential experience of everyday life with systemic lupus erythematosus. J Adv Nurs. 2018;74(5):1170-9. https://doi.org/10.1111/jan.13525

19. Sloan M, Harwood R, Sutton S, D'Cruz D, Howard P, Wincup C, et al. Medically explained symptoms: A mixed methods study of diagnostic, symptom and support experiences of patients with lupus and related systemic autoimmune diseases. Rheumatol Adv Pract. 2020;4(1):rkaa006. https://doi.org/10.1093/rap/rkaa006 
20. Beckerman NL. Living with lupus: a qualitative report. Soc Work Health Care. 2011;50(4):330-43. https://doi.org/10.1080/00981389.2011.554302.

21. McElbhone K, Abbott J, Gray J, Williams A, Teh LS. Patient perspective of systemic lupus erythematosus in relation to health-related quality of life concepts: a qualitative study. Lupus. 2010;19(14):1640-7. 10.1177/0961203310378668.

22. Valencia-Toro PA, Claudia Mora K, Arbeláez AM, Jaimes DA, Yahia G, Plazas M, et al. ¿Cuál es la percepción de enfermedad de pacientes colombianos con lupus eritematoso sistémico?: aplicación del revised illness perceptions questionnaire (IPQ-R). Rev Colomb Reumatol. 2014;21(1):4-9. https://doi.org/10.1016/S0121-8123(14)70141-0

23. Santos LMO, Vilar MJ, Maia EMC. Mulheres com lúpus eritematoso sistêmico, sintomas depressivos e apoio social. Psicol Saude Doencas. 2017;18(1):39-54. http://doi.org/10.15309/17psd180104

24. Antonechen AC, Pelaez Dóro M. Qualidade de vida, ansiedade e depressão em pacientes da hemato-onco com dor crônica. Saude (St Maria). 2016;42(1):225-34. http://doi.org/10.5902/2236583419001

25. Kim HY, Park JH, Lee JB, Kim SJ. A case of dystrophic calcification in the masseter muscle. Maxillofac Plast Reconstr Surg. 2017;39(1):31. https://doi.org/10.1186/s40902-017-0130-4

26. Waldheim E, Ajeganova S, Bergman S, Frostegård J, Welin E. Variation in pain related to systemic lupus erythematosus (SLE): a 7-year followup study. Clin Rheumatol. 2018;37(7):1825-34. https://doi.org/10.1007/s10067-018-4079-1

27. Jesus PBR, Santos I, Brandão ES. A autoimagem e a autoestima das pessoas com transtornos de pele: uma revisão integrativa da literatura baseada no modelo de Callista Roy. Aquichan. 2015;15(1):75-89. http://doi.org/10.5294/aqui.2015.15.1.8

28. Asano NMJ, Coriolano MGWS, Asano BJ, Lins OG. Psychiatric comorbidities in patients with systemic lupus erythematosus: a systematic review of the last 10 years. ver Bras Reumatol. 2013;53(5):431-7. http://doi.org/10.1590/S0482-50042013000200009.

29. Mesquita NA, Zamarioli CM, Fulquini FL, Carvalho EC, Angerami ELS. Social networks in nursing work processes: an integrative literature review. Rev Esc Enferm USP. 2017;51:e03219. http://doi.org/10.1590/S1980-220X2016021603219

30. Costa LM, Coimbra CCBE. Lúpus eritematoso sistêmico: incidência e tratamento em mulheres. Rev Uningá. 2014[cited 2019 Jul 5];20(1):81-6. Available from: https://www.mastereditora.com.br/periodico/20141001_084139.pdf

31. Phuti A, Schneider M, Makan K, Tikly M, Hodkinson B. Living with systemic lupus erythematosus in South Africa: a bitter pill to swallow. Health Qual Life Outcomes. 2019;17(1):65. https://doi.org/10.1186/s12955-019-1132-y

32. Rutter SJ, Kiemle G. Exploring the social and interpersonal experiences of South Asian women with a diagnosis of Systemic Lupus Erythematosus. Psychol Health. 2015;30(3):318-35. https://doi.org/10.1080/08870446.2014.972397

33. Silva ACS, Amorim EC, Silva GG, Silva JS, Correia DS. Lúpus: efeitos nos cuidados de si e nas relações familiares. Psicol Rev. 2013;19(1):30-42. https://doi.org/10.5752/P.1678-9563.2013v19n1p30

34. Garbi MOSS, Hortense P, Gomez RRF, Silva TCR, Castanho ACF, Sousa FAEF. Pain intensity, disability and depression in individuals with chronic back pain. Rev Latino-Am Enfermagem. 2014;22(4):569-75. https://doi.org/10.1590/0104-1169.3492.2453

35. Jesus MCP, Capalbo C, Merighi MAB, Oliveira DM, Tocantins FR, Rodrigues BMRD, Ciuffo LL. The social phenomenology of Alfred Schütz and its contribution for the nursing. Rev Esc Enferm USP. 2013;47(3):728-33. https://doi.org/10.1590/S0080-623420130000300030

36. Sutanto B, Singh-Grewal D, McNeil HP, O'Neill S, Craig JC, Jones J et al. Experiences and perspectives of adults living with systemic lupus erythematosus: thematic synthesis of qualitative studies. Arthritis Care Res (Hoboken). 2013;65(11):1752-65. https://doi.org/10.1002/ acr.22032

37. Lisboa A, Brito I, Figueiredo C. Lúpus eritematoso sistêmico e gravidez: implicações terapêuticas. Arq Med [Internet]. 2014 [cited 2019 Jul 26];28(1):18-24. Available from: https://scielo.pt/pdf/am/v28n1/v28n1a04.pdf

38. Olesińska M, Saletra A. Quality of life in systemic lupus erythematosus and its measurement. Reumatol. 2018;56(1):45-54. https://doi. org/10.5114/reum.2018.74750 